\title{
Algae and physico-chemical characteristics of Adani rice field, Enugu State, Nigeria
}

\author{
Nkechinyere O. Nweze ${ }^{1}$ and Bartholomew O. Ude ${ }^{2}$ \\ ${ }^{1}$ (Department of Plant Science and Biotechnology, University of Nigeria, Nsukka)
}

\begin{abstract}
The algae and physico-chemical characteristics of Adani rice field in Enugu State, Nigeria were studied during the wet season. Light microscopy was used for phycological studies and algae identified using text books, taxonomic keys and materials from the internet. Physico-chemical parameters were analyzed using the methods of American Public Health Association. Pearson correlation $(P \leq 0.01)$ and percentages were calculated to check for the relationships between the investigated parameters. A total of eight algal taxa belonging to Chlorophyta, Cyanophyta, Euglenophyta and Bacillariophyta in order of decreasing abundance were recorded. The total Chlorophyta, Cyanophyta, and Euglenophyta populations showed significant positive correlations with ammonia, monthly mean rainfall and lead respectively. Significant negative correlations were observed between water temperature and calcium; depth and TDS; TDS and nitrate, phosphate, potassium and zinc; $p H$ and chloride and magnesium. Significant positive correlations were observed between depth and nitrate, phosphate, potassium and zinc; dissolved oxygen and nitrate; total alkalinity and calcium; chloride and calcium.
\end{abstract}

Keywords: Algae, Physico-chemical Parameters, Rice Field

\section{Introduction}

Wetlands all over the world are inextricably linked with agriculture. Rice which supports about half the world's populations [1] is grown largely in natural and human-made wetlands. In this agro-ecological system the problem associated with inorganic fertilization in terms of cost, availability and pollution could be tackled to a great extent by biological nitrogen fixation. Roger [2] reported that traditional wetland rice cultivation is sustained on account of this biological nitrogen fixation. Quantitatively, nutrients input and crop yield increase on account of algal contributions especially the blue-green algae (BGA), a group of biological nitrogen fixers $[2,3]$.

1.1. Common rice field algae. Pantastico and Suayan [4] observed Chlorophyta, Cyanophyta, Chrysophyta and Euglenophyta as the four major algal divisions in the Phillipines rice fields and [5] recorded three phyla (Chlorophyta, Cyanophyta and Euglenophyta) in Assint rice fields in Egypt. Their observations agreed with reports by [6] that the Bacillariophyta, Chlorophyta and Cyanophyta constitute the three major groups of algae in freshwater ecosystems.

Rice fields in Nigeria cut across from the mangrove swamps of the Niger Delta to arid areas near Lake Chad [7]. Like some wetlands of the world, these rice fields have not been adequately investigated [2]; hence information on algae from them is very scanty.

\section{Factors That Affect Algae in Rice Field}

2.1. Physico-chemical parameters. The flooded rice fields as wetlands provide environments that affect the growth of algae with respect to their requirements for water, light, temperature, and soil nutrients as well as the farming practices [8].

Water is the medium where algae draw dissolved nutrients in solution. Besides the associated dilution effects, increased water levels can also differentially reduce phytoplankton density and productivity by creating habitat space for zooplankton that graze selectively on planktonic forms of algae [9].

Of all the habitat factors which affect phytoplankton in rice fields, light is the most important [10]. Algae as photosynthetic microorganisms are restricted to the photic zone. However, light tolerance differs between algal species and may be roughly correlated with taxonomic groups [10]. Therefore, light may have a selective effect on their floral compositions [11]. Many green algae are adapted to high light conditions, diatoms and chrysophytes seem to be indifferent to light, while the blue-green algae are generally sensitive to high light intensities and may be regarded as low light species [11].

Temperature influences both algal biomass composition and productivity [10]. Sobrino and Neale [12] opined that temperature rise usually increases growth and photosynthesis because of a correlated enhancement of enzymatic activity. Similar to sunlight, the temperature may also have a species-selective effect on algae [8]. 
$\mathrm{pH}$ another important factor of rice field floodwater is reported to have positive correlations with blue-green algae; but show negative correlations with the growth of Chlorophyceae [10].

The nutrients requirements and need for different species of algae differ [8]. Roger and Kulasooriya [10] Reported that under nitrogen-deficient conditions, $\mathrm{N}_{2}$-fixing blue-green algae are greatly favoured; observing also that though algal requirements for phosphorus differ among species for optimal growth when no external factor is limiting, no conclusions could be made about the relationship between phosphorus requirements and algal taxonomic groups. Potassium as essential as it is for algae, was reported to be present in natural waters in concentrations that phytoplankton growth is not limited by it [13]. However, concentrations high enough to inhibit the growth of Dinobryon were commonly found in many freshwaters [14].

2.2. Agricultural practices. Moreover, the most profound effects on the rice field algae may be those resulting from human intervention or farming practices. Tillage results in the incorporation of algae and their spores into the soil and the dispersion of clay particles in the water; which give advantage to flagellate algae that are capable of moving to the surface for re-colonization. Fertilizer types, method of application and micronutrients used affect algal taxonomic groups differently [8]. Pesticides and common rice field chemicals are reported to be inhibitory [15], selective, or even stimulatory [10] to algae. Besides, [16] reported that the resistance to high levels of pesticides seems to be more characteristic of BGA than of the eukaryotic algae.

Studies on water bodies in Adani area had focused on fisheries and micro-invertebrate fauna [17] and macro-algae [18]. This work is therefore the first attempt at documenting the micro-algal flora in relation to the physico-chemical environments of this area. The objectives of the study were to identify and estimate the populations of algae that occur in Adani rice field; assess the periodicity and distribution of the algal population; assess some of the physico-chemical characteristics of this location; and study the possible interactions among the parameters investigated.

\section{Materials and Methods}

3.1. Study area. Adani belongs to the rice-producing area of Adani-Umubo-Aguleri [19]. The area lies between latitudes $6^{\circ} 00 \mathrm{~N}$ and $7^{\circ} 00 \mathrm{~N}$ and longitudes $7^{\circ} 00 \mathrm{E}$ and $8^{\circ} 00 \mathrm{E}$, along the flood plains of Anambra, Obina, Omambala, Ezu, and Do Rivers [17] (Fig. 1). The location is part of the undulating plain of the western reaches of the dip slope of Nsukka, described by [20] as part of the Anambra River plains lying $125 \mathrm{~m}$ above sea level. Rice cultivation is limited to the seasonally flooded lands bordering these rivers [7]. Two main seasons prevail in this area - dry season (November to March) and wet season (April to October) with a short break between late July and early August. Due to its latitudinal location, the area receives abundant and constant insolation with mean annual temperature above $21{ }^{\circ} \mathrm{C}[21]$. The area has high relative humidity during the wet season and low values during the dry season months. Total annual rainfall ranges between $1500-1830 \mathrm{~mm}$ in the area [22]. The soils are made up of sandstone, shale, mudstone, sand-shale and coal seams $[20,18]$. The mineral deposits found include iron, clay, coal and shale [23]. The vegetation is a derived Savanna [18].

The major land uses in the area are agricultural. The farmers make use of farmyard, compost and green manures; and different combinations of NPK and urea fertilizers. Fishing is also carried out in the rivers and some depressions - pits and canals by different methods which include pumping out water from these depressions, and the use of hook, line and sinker.

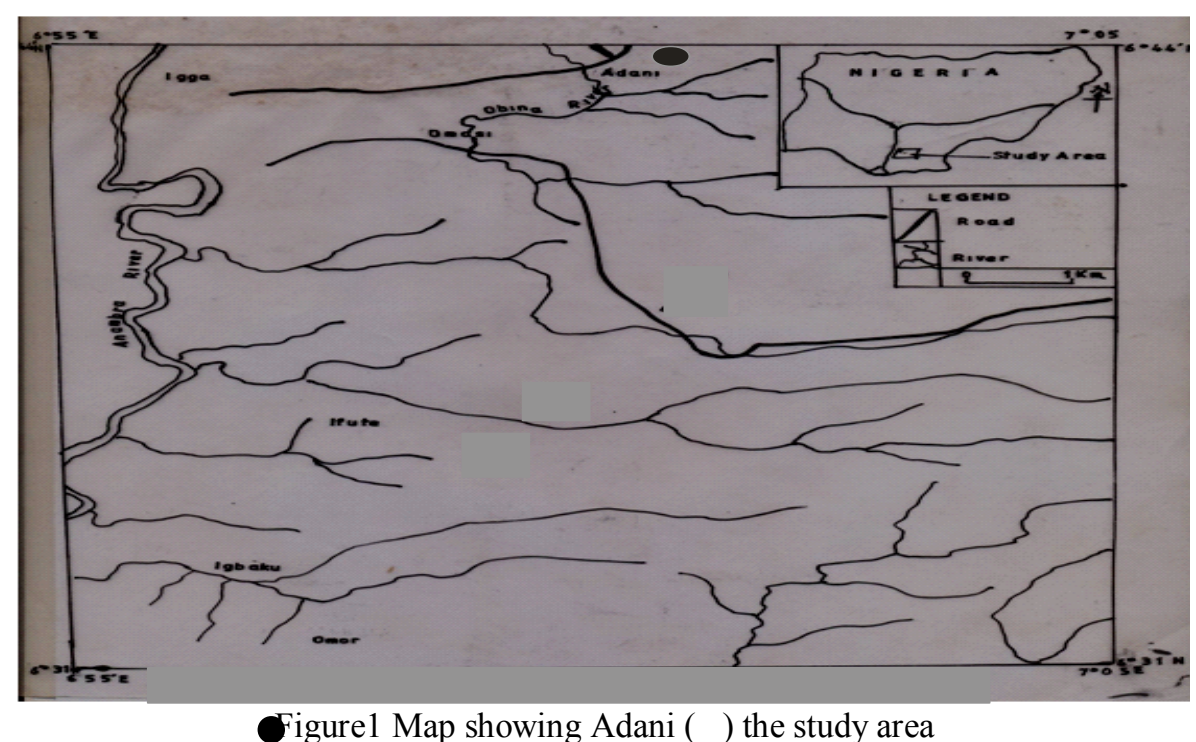

igure1 Map showing Adani ( ) the study area 
3.2. Meteorological data. The meteorological data for monthly mean rainfall and relative humidity for the period of investigation were collected from the Department of Crop Science, University of Nigeria, Nsukka.

3.3. Sample collection and analyses. Samples for algal studies were collected with about $500 \mathrm{ml}$ wide-mouth plastic containers and preserved immediately with Lugol's iodine solution in ratio of 1 part to 100 parts of the sample [24]. Taxonomic key and text books $[25,26]$ were used for algae identification after microscopic examinations using a light binocular microscope (Olympus model). The depth was measured in the field with a metre rule. Water temperature and $\mathrm{pH}$ were also investigated in situ with a mercury-in-bulb thermometer of $0.1^{\circ} \mathrm{C}$ calibrations and a battery-operated $\mathrm{pH}$ meter (Hanna model) respectively. Samples for physico-chemical studies were collected with three litre plastic containers. The colour, dissolved oxygen (DO), total alkalinity (TA), ammonia, silica, phosphate, sulphate, total suspended solids (TSS), total dissolved solids (TDS), total hardness $(\mathrm{TH})$, calcium, magnesium, nitrate, chloride, chemical oxygen demand (COD), biochemical oxygen demand (BOD), potassium, iron, lead, zinc, and copper were analyzed following the standard methods [27]. Means and percentages of data collected were calculated. Data obtained were subjected to Pearson correlation at $\mathrm{P} \leq 0.05$ probability using SPSS Version 16 .

\section{Results}

4.1. Meteorological data. There were temporal variations in the meteorological data obtained. The monthly mean rainfall ranged from $0-326.02 \mathrm{~mm}$; the lowest value was obtained in January and February and the highest in September. The mean value was $136.51 \pm 33.45 \mathrm{~mm}$. The monthly mean relative humidity was highest in August with a value of $79.55 \%$ and lowest in January $(56.03 \%)$ and the mean was $72.80 \pm 2.32 \%$ (Figs. 2 and 3).

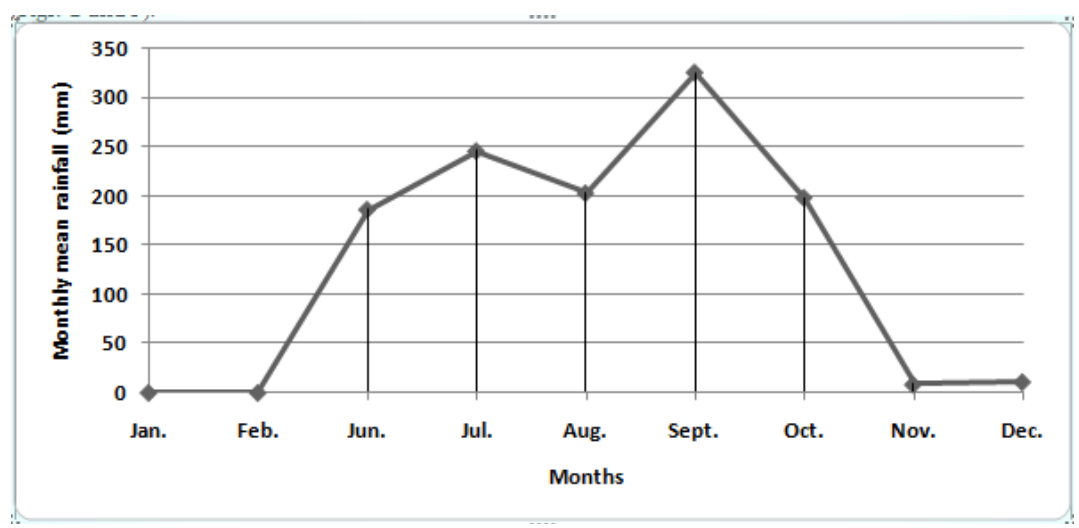

Figure 2 Monthly mean rainfall during investigation

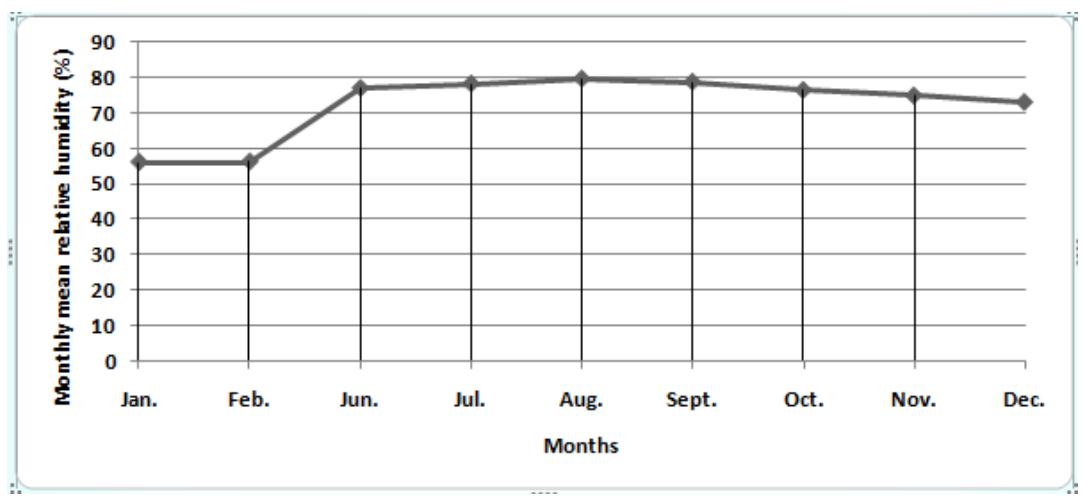

Figure 3 Monthly mean relative humidity during investigation

4.2. The algae. Algae belonging to four phyla - Bacillariophyta, Chlorophyta, Cyanophyta and Euglenophyta were encountered (Table 1). The range for monthly total algal density was $340-1060$ individuals $/ \mathrm{ml}$ obtained in August and September respectively. Bacillariophyta (8.62\%) ranged from $0-200$ individuals $/ \mathrm{ml}$ with the lowest population in June and July and highest in October; and mean value of $60 \pm 36$ individuals $/ \mathrm{ml}$. Bacillariophyta (diatoms) were represented by Navicula sp. Chlorophyta (54.02\%) ranged from $60-720$ individuals $/ \mathrm{ml}$; obtained in June and July respectively. The mean value was $376 \pm 122$ individuals $/ \mathrm{ml}$ and they were represented by Ankistrodesmus falcatus (Corda.) Ralfs, Closterium setaceum Ehrenberg ex Ralfs, Micrasterias radiata Hass. and Spirogyra fluviatilis Hilse. Cyanophyta (25.86\%) ranged from $0-800$ 
individuals $/ \mathrm{ml}$ with the lowest value obtained in June, July and October and the highest in September; had a mean value of $180 \pm 156$ individuals $/ \mathrm{ml}$ and were represented by Synechocytis linckia (Roth.) Bor. \& Flah. and Nostoc aquatilis Sauv. The total Euglenophyta (11.49\%) ranged from $0-200$ individuals/ml with the lowest value obtained in August, September and October; and the highest value in June and July, with mean value of 80 \pm 48 individuals $/ \mathrm{ml}$; the group was represented by Euglena acus Ehrenberg.

Table 1 Monthly Variations in Algal Density (Individual/ml) and Compositions during Investigation

\begin{tabular}{|c|c|c|c|c|c|c|c|}
\hline$\underset{\mathbb{Z}}{\stackrel{\mathscr{g}}{\gtrless}}$ & $\stackrel{\Xi}{\Xi}$ & $\stackrel{2}{\Xi}$ & 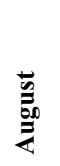 & 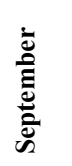 & $\begin{array}{l}\bar{\Xi} \\
\bar{\Xi} \\
\bar{\Xi} \\
0\end{array}$ & 吾 & ○。 \\
\hline \multicolumn{8}{|l|}{ Bacillariophyta } \\
\hline Navicula sp. & $\mathbf{0}$ & $\mathbf{0}$ & 60 & 40 & 200 & 300 & 8.62 \\
\hline Total & $\mathbf{0}$ & o & 60 & 40 & 200 & 300 & 8.62 \\
\hline \multicolumn{8}{|l|}{ Chlorophyta } \\
\hline Ankistrodesmus falcatus (Corda.) Ralfs & $\mathbf{0}$ & 200 & 120 & 60 & 200 & 580 & 16.67 \\
\hline Closterium setaceum Ehrenberg ex Ralfs & $\mathbf{0}$ & 120 & 160 & 160 & 400 & 840 & 24.14 \\
\hline Micrasterias radiata Hass & 60 & $\mathbf{0}$ & $\mathbf{0}$ & $\mathbf{0}$ & $\mathbf{0}$ & 60 & 1.72 \\
\hline Spirogyra fluviatilis Hilse & $\mathbf{0}$ & 400 & $\mathbf{0}$ & $\mathbf{0}$ & $\mathbf{0}$ & 400 & 11.49 \\
\hline $\begin{array}{l}\text { Total } \\
\text { Cyanophyta }\end{array}$ & 60 & 720 & 280 & 220 & 600 & 1880 & 54.02 \\
\hline Nostoc linckia (Roth.) Bor. \& Flah. & $\mathbf{0}$ & $\mathbf{0}$ & $\mathbf{0}$ & 800 & $\mathbf{0}$ & 800 & 22.99 \\
\hline Synechocystis aquatilis Sauv. & 100 & $\mathbf{0}$ & $\mathbf{0}$ & $\mathbf{0}$ & $\mathbf{0}$ & 100 & 2.87 \\
\hline Total & 100 & $\mathbf{0}$ & 0 & 800 & 0 & 900 & 25.86 \\
\hline \multicolumn{8}{|l|}{ Euglenophyta } \\
\hline Euglena acus Ehrenberg & 200 & 200 & $\mathbf{0}$ & $\mathbf{0}$ & $\mathbf{0}$ & 400 & 11.49 \\
\hline $\begin{array}{l}\text { Total } \\
\text { Grand total }\end{array}$ & $\begin{array}{l}200 \\
360\end{array}$ & $\begin{array}{l}200 \\
920\end{array}$ & $\begin{array}{l}0 \\
340\end{array}$ & $\begin{array}{l}0 \\
1060\end{array}$ & $\begin{array}{l}0 \\
800\end{array}$ & 400 & 11.49 \\
\hline
\end{tabular}

4.3. Variations in the physico-chemical parameters. Monthly variations in physico-chemical parameters are presented in Table 2. Mean water temperature was $32 \pm 1.79{ }^{\circ} \mathrm{C}$. The maximum and minimum values were 37 ${ }^{\circ} \mathrm{C}$ and $26{ }^{\circ} \mathrm{C}$ obtained in June and August respectively. Depth ranged from 9.8 to $30 \mathrm{~cm}$. The maximum and minimum values occurred in June and July respectively; the mean value was $13.96 \pm 4.01 \mathrm{~cm}$. The range for colour was $70-280$ Hazen units; the highest value occurred in June and lowest value in October; the mean value was $207.5 \pm 40.3$ Hazen units. Total alkalinity range was $1.4-9.05 \mathrm{mg} / \mathrm{l}$. The lowest and the highest values were obtained in June and August respectively; the mean value was $4.25 \pm 1.34 \mathrm{mg} / \mathrm{l}$. pH ranged from 4 7.9 which occurred in August and September respectively. The mean was $6.3 \pm 0.72$. Total dissolved solids were highest in September and October with a value of $0.13 \mathrm{mg} / \mathrm{l}$ and lowest in June with a value of $0.01 \mathrm{mg} / \mathrm{l}$; and the mean was $0.1 \pm 0.023 \mathrm{mg} / \mathrm{l}$. Total suspended solids ranged from $0.01-0.15 \mathrm{mg} / \mathrm{l}$. The maximum value was obtained in August and lowest value in June and July. The mean value was $0.07 \pm 0.027$.

Dissolved oxygen range was $3.9-10.10 \mathrm{mg} / \mathrm{l}$; lowest value occurred in July and the highest in June; the mean was $6.29 \pm 1.13 \mathrm{mg} / \mathrm{l}$. The percentage oxygen saturation ranged from $54.42-150.39 \%$; obtained in July and June respectively; and the mean was $87.26 \pm 17.62 \%$. Chemical oxygen demand range was $28-380$ $\mathrm{mg} / \mathrm{l}$; the lowest value was obtained in August while the highest occurred in July and the mean value was $110 \pm$ $67.63 \mathrm{mg} / \mathrm{l}$. Biological oxygen demand ranged from $8-43 \mathrm{mg} / \mathrm{l}$; observed in August and September respectively. The mean value was $22.6 \pm 6.65 \mathrm{mg} / \mathrm{l}$.

Phosphate ranged from $1.967-3.54 \mathrm{mg} / \mathrm{l}$. The lowest value occurred in October and the highest in September. The mean value was $2.77 \pm 0.3 \mathrm{mg} / \mathrm{l}$. The range for ammonia was $18-40 \mathrm{mg} / \mathrm{l}$ observed in June and October respectively and the mean was $29 \pm 4 \mathrm{mg} / \mathrm{l}$. Nitrate ranged from $0.48-1.70 \mathrm{mg} / \mathrm{l}$, obtained in September and June respectively and the mean value was $0.78 \pm 0.23 \mathrm{mg} / \mathrm{l}$. Potassium had a range of $0.5-$ $2.65 \mathrm{mg} / \mathrm{l}$; its lowest value was obtained in August and the highest in June and the mean was $1.13 \pm 0.39 \mathrm{mg} / \mathrm{l}$.

Total hardness range was $0-14 \mathrm{mg} / \mathrm{l}$; the lowest value occurred in June and highest in August; the mean was 7.6 $\pm 2.79 \mathrm{mg} / \mathrm{l}$. Calcium range was $0.8-9.6 \mathrm{mg} / \mathrm{l}$; the lowest value was obtained in June while the highest value occurred in August; the mean value was $3.2 \pm 1.62 \mathrm{mg} / \mathrm{l}$. Sulphate range was $2.58-9.46 \mathrm{mg} / \mathrm{l}$. The lowest value occurred in July and the highest value in June and the mean was $4.1 \pm 1.35 \mathrm{mg} / \mathrm{l}$. Magnesium range was $2-$ $24.30 \mathrm{mg} / \mathrm{l}$ with lowest value obtained in July and the highest in September; and the mean was $12.07 \pm 3.97$ $\mathrm{mg} / \mathrm{l}$. The range for silica was $0.25-0.5 \mathrm{mg} / \mathrm{l}$; lowest value was obtained in August and the highest value in July with mean of $0.36 \pm 0.04$. The range for chloride was $1-59.98 \mathrm{mg} / \mathrm{l}$. The lowest value occurred in September and the highest value during August; the mean was $17.6 \pm 11.13 \mathrm{mg} / \mathrm{l}$. 
Iron ranged from $0.01-3.01 \mathrm{mg} / 1$; the lowest value occurred in October and the highest in June. The mean was $1.12 \pm 0.66 \mathrm{mg} / \mathrm{l}$. Lead concentration ranged between $0.003-0.128 \mathrm{mg} / \mathrm{l}$; the lowest value occurred in September and the highest in July. The mean was $0.05 \pm 0.02 \mathrm{mg} / \mathrm{l}$. Copper ranged between $0-0.423 \mathrm{mg} / \mathrm{l}$. The lowest value was obtained in June and July while the highest value was recorded in August. The mean value was $0.23 \pm 0.9 \mathrm{mg} / \mathrm{l}$. The range for zinc was $0-16.345 \mathrm{mg} / \mathrm{l}$. The lowest value was obtained in July and August and the highest in June. The mean value was $5.23 \pm 3.03 \mathrm{mg} / \mathrm{l}$.

4.4. Correlation analyses amongst the investigated parameters in Adani rice field. Correlation analyses $(\mathrm{P} \leq$ 0.01 ) amongst the investigated parameters revealed significant positive correlations between monthly rainfall and total Cyanophyta population $(\mathrm{r}=0.884)$; total Euglenophyta population and total suspended solids and lead $(\mathrm{r}=0.913$ and 0.894 respectively); copper and total hardness $(\mathrm{r}=0.992)$; ammonia and total Chlorophyta population $(\mathrm{r}=0.948)$. Significant negative correlations were observed between Euglenophyta and iron and copper $(r=-0.888$ and -0.979 respectively). There was no significant correlation observed between the algal phyla.

Significant relationships were observed among physico-chemical parameters. Negative correlations were observed between water temperature and calcium $(\mathrm{r}=-0.911)$; depth and TDS $(\mathrm{r}=-1.00)$; TDS and: nitrate $(r=-0.987)$, phosphate $(r=-1.00)$, potassium $(-0.972)$ and zinc $(r=-0.917)$ respectively; TSS and silica $(\mathrm{r}=-0.910)$. Also, significant negative correlations were observed for $\mathrm{pH}$ and chloride and magnesium $(\mathrm{r}$ $=-0.939$ and -0.886 respectively); silica and copper $(r=-0.908)$; lead and iron and copper $(r=-0.908$ and 0.909 respectively).

On the other hand significant positive correlations were observed between relative humidity and sulphate $(\mathrm{r}=0.913)$; depth and: nitrate, phosphate, potassium and zinc $(\mathrm{r}=0.987,1.00,0.971,0.919$ respectively); TSS and TH and copper $(r=0.963$ and 0.952 respectively); TH and copper $(r=0.992)$; DO and nitrate $(\mathrm{r}=0.880)$; COD and lead $(\mathrm{r}=0.882)$; TA and calcium $(\mathrm{r}=0.899)$; silica and lead $(\mathrm{r}=0.959)$; chloride and calcium $(\mathrm{r}=0.899)$; nitrate and phosphate $(\mathrm{r}=0.986)$, potassium and phosphate and zinc $(\mathrm{r}=0.968$ and 0.939 respectively); and between iron and copper $(\mathrm{r}=0.893)$.

Table 2 Monthly variations in the physico-chemical parameters during investigation

\begin{tabular}{|c|c|c|c|c|c|c|}
\hline \multirow[t]{2}{*}{ Physico - chemical Parameters } & \multicolumn{6}{|l|}{ Months } \\
\hline & June & July & Aug. & Sept. & Oct. & Mean \pm S.E \\
\hline Water temperature $\left({ }^{\circ} \mathrm{C}\right)$ & 37 & 33 & 26 & 31 & 33 & $32 \pm 1.79$ \\
\hline Relative humidity (\%) & 76.9 & 78.2 & 79.6 & 78.7 & 76.4 & $77.96 \pm 0.58$ \\
\hline Monthly mean rainfall (mm) & 186.4 & 246.1 & 203.2 & 326 & 198.6 & $232.06 \pm 25.55$ \\
\hline Depth $(\mathrm{cm})$ & 30 & 9.8 & 10 & 10 & 10 & $13.96 \pm 4.01$ \\
\hline Colour (Hazen Units) & 280 & 250 & 275 & 163 & 70 & $207.6 \pm 40.34$ \\
\hline Total dissolved solids (mg/l) & 0 & 0.1 & 0.1 & 0.1 & 0.1 & $0.08 \pm 0.022$ \\
\hline Total suspended solids (mg/l) & 0.01 & 0.01 & 0.15 & 0.09 & 0.09 & $0.07 \pm 0.027$ \\
\hline Total hardness (mg/l) & 0 & 2 & 14 & 12 & 10 & $7.6 \pm 2.79$ \\
\hline Coliform MPN/100ml & 1100 & 460 & 43 & 3 & 14 & $324 \pm 211.99$ \\
\hline Dissolved oxygen (mg/l) & 10.1 & 3.9 & 6.5 & 4.1 & 6.87 & $6.294 \pm 1.13$ \\
\hline$\%$ oxygen $\%$ saturation & 150.39 & 54.42 & 80.31 & 55.32 & 95.87 & $87.262 \pm 17.62$ \\
\hline Chem. oxygen demands (mg/l) & 50 & 380 & 28 & 40 & 52 & $110 \pm 67.63$ \\
\hline Bioch. oxygen demand (mg/l) & 22 & 9 & 8 & 43 & 31 & $22.6 \pm 6.65$ \\
\hline $\mathrm{pH}$ & 5.3 & 7.3 & 4 & 7.9 & 7 & $6.3 \pm 0.72$ \\
\hline Total alkalinity (mg/l) & 1.4 & 5 & 9.05 & 2.3 & 3.5 & $4.25 \pm 1.34$ \\
\hline Silica (mg/l) & 0.4 & 0.5 & 0.25 & 0.3 & 0.35 & $0.36 \pm 0.04$ \\
\hline Chloride (mg/l) & 20 & 4 & 60 & 1.00 & 3.00 & $17.6 \pm 11.12$ \\
\hline Nitrate (mg/l) & 1.7 & 0.55 & 0.5 & 0.48 & 0.69 & $0.784 \pm 0.23$ \\
\hline Sulphate (mg/l) & 9.46 & 2.58 & 2.7 & 2.8 & 2.7 & $4.048 \pm 1.35$ \\
\hline Phosphate (mg/l) & 2.2 & 3 & 3.2 & 3.5 & 2 & $2.78 \pm 0.300$ \\
\hline Ammonia (mg/l) & 18 & 36 & 27 & 24 & 40 & $29 \pm 4.00$ \\
\hline Potassium (mg/l) & 2.65 & 0.9 & 0.5 & 0.6 & 1 & $1.13 \pm 0.39$ \\
\hline Calcium (mg/l) & 0.8 & 1.6 & 9.6 & 2.4 & 1.6 & $3.2 \pm 1.62$ \\
\hline Iron (mg/l) & 3.01 & 0.17 & 2.41 & 0.02 & 0.01 & $1.124 \pm 0.66$ \\
\hline Magnesium (mg/l) & 4.86 & 2 & 14.6 & 24.3 & 14.6 & $12.072 \pm 3.97$ \\
\hline
\end{tabular}


Algae and physico-chemical characteristics of Adani rice field, Enugu State, Nigeria

\begin{tabular}{lllllll}
\hline & \multicolumn{1}{l}{} \\
\hline Lead (mg/l) & 0.07 & 0.13 & 0.01 & 0 & 0.03 & $0.048 \pm 0.023$ \\
Zinc (mg/l) & 16.35 & 0 & 0 & 3.269 & 6.538 & $5.231 \pm 3.03$ \\
Copper (mg/l) & 0 & 0 & 0.423 & 0.392 & 0.308 & $0.225 \pm 0.09$ \\
\hline
\end{tabular}

\section{Discussion}

5.1. Algae and physico-chemical parameters. The highest population of algae was recorded in September, followed by July, October, June and August populations in decreasing order. The greater abundance of Chlorophyta may be related to the acid nature of the water, a reflection of the acid soil reported by [18]. In addition, high light intensity characteristic of the tropics favours the development of Chlorophyta [10]. The observed algal groups (Bacillariophtya, Chlorophyta, Cyanophyta and Euglenophyta) are in agreement with the observations of [4] on Phillipines rice fields; [5] in Assint rice fields, Egypt; and [6] as the major groups of algae in freshwater ecosystems.

The significant positive correlations between total Cyanophyta and total Chlorophyta populations with mean monthly rainfall and ammonia respectively suggest that rainfall may have increased the supply of the nutrients for the phytoplankton via runoff; while ammonia increase may also have raised the supply of nitrate needed by algae as nutrient [28]. The significant negative correlations between total Euglenophyta and TSS, TH, iron and copper could be as a result of the utilization these elements (TSS, TH and iron) as nutrients by the algae $[29,30]$ more than they were replenished from their sources. Copper has been reported to kill algae at high concentration.

5.2. The physico-chemical parameters. The significant negative correlation between the depth (volume) of water and TDS suggested that the dilution effect of water reduced the concentrations of the substances which contributed to TDS [29]. However, significant positive correlations between depth and nitrate, phosphate, potassium and zinc suggest that these elements may have been supplied via runoff water from agricultural farmland which also elevated the depth of water in the field [28]. The significant negative correlations between TDS and nitrate, phosphate, potassium and zinc suggest that these nutrients constituted TDS from the water by replacement reaction [31]. The significant positive correlations between TSS and TH and $\mathrm{Cu}$ may suggest that copper and salts that contributed to total hardness made up the suspended solids in the floodwater; while the negative correlation between TSS and silica could suggest that silicates solubilized suspended solids [31]. The significant positive correlation between $\mathrm{TH}$ and $\mathrm{Cu}$ suggests that copper and total hardness salts were components of the soil [32]. The observed significant negative correlation between water temperature and calcium conforms to the observation of [33] that calcium ion increases in cold. Dissolved oxygen showed temporal variations and was super-saturated in June when algal populations were high. The significant positive correlation between DO and nitrate agrees with the observation by [26] that dissolved oxygen greatly enhances nitrification. The significant positive correlation between COD and lead suggests that the lead came from anthropogenic sources [32].

The significant negative correlations between $\mathrm{pH}$ and chloride and magnesium respectively suggest that magnesium occurred in the floodwater as magnesium chloride which increased the acidity of the water (lowering the $\mathrm{pH}$ ). The significant positive correlation between TA and calcium supported the claim by [26] that this element contributes to the alkalinity of water. The significant positive correlation between chloride and calcium suggests that calcium occurred as calcium chloride [33]; while the significant positive correlations nitrate and phosphate, potassium and zinc showed that these compounds could have possibly come from a common source, NPK fertilizer [33]. The same reason may explain the significant positive correlations between phosphate with potassium and zinc, and potassium and zinc.

Perhaps, as a result of coming from a common source (soil) iron and copper correlated significantly positively with each other and the significant positive correlation between silica and lead could be as a result of the elements constituting the soil [32]; while replacement reaction may explain the significant negative correlations between silica and copper where silica replaced copper [34]; and between iron and lead [31].

\section{Conclusion}

The algal groups observed in Adani rice field have been recorded in Asian (Phillipines) and Assint (Egypt) rice fields; and many freshwater ecosystems. The prevailing conditions in this rice field ecosystem, especially high light intensity characteristic of the tropics and $\mathrm{pH}$ favoured the Chlorophyta over the other groups in terms of populations and diversity. Of the 8 taxa recorded (Navicula sp., Ankistrodesmus falcatus, Closterium setaceum, Micrasterias radiata, Spirogyra fluviatilis, Nostoc linckia, Synechocystis aquatilis and Euglena acus), 4 belonged to the Chlorophyta indicating the greater adaptability of the group to prevailing environmental conditions in the rice field. However, by September when the water became alkaline $(\mathrm{pH}=7.9)$, Cyanophyta had the highest population confirming that the growth of this group was promoted by alkaline condition. Besides, the physico-chemical parameters showed patterns with previous reports on African 
freshwaters. Some of them showed significant positive and negative correlations with one another and the algal groups; an indication that some of them were nutrient sources for the phytoplankton.

\section{References}

[1] Z. Manzoor, R. I. Ali, T. H. Awan, N. Khalid and M. Ahmad, Appropriate time of nitrogen application to fine rice, Oryza sativa, Journal of Agricultural Research, 44(4), 2006, 261-267.

[2] P. A. Roger, Biology and management of the floodwater ecosystem in rice fields (Philippines: International Rice Research Institute, 1996).

[3] U. Mishra, and S. Pabbi, Cyanobacteria: a potential biofertilizer for rice, Resonance, 2004, 1-10.

[4] J. B. Pantastico, and Z. A. Suayan, Algal succession in the rice field of college and Bay Laguna, Philippines, Agriculture 57, 1974, 313-326.

[5] A. A. Issa, M. S. Adam, A. A. Mohammed, and A. F. Hifney, A comparative study of algal communities on cultivated and uncultivated soils, Pakistan Journal of Biological Sciences, 3(4), 2000, 615-620.

[6] B. A. Fonge, A. S. Tening, E. A. Egbe, G. S. Yinda, A. N. Fongod, and R. M. Achu, Phytoplankton diversity and abundance in Ndop wetland plain, Cameroon, African Journal of Environmental Science and Technology, 6(6), 2012, 247-257.

[7] S. R. Longtau, Multi-agency partnerships in west African agriculture: a review and description of rice production systems in Nigeria (Jos, Nigeria: Department for International Development (DFID), 2003).

[8] M. Halwart, and M. V. Gupta (Eds.), Culture of fish in rice fields (Rome, Italy: FAO and the World Fish Center, 2004).

[9] United State Environmental Protection Agency, Algal and microbial communities as indicators of prairie wetland integrity: bioindicators for assessing ecological integrity of prairie wetlands (Washington DC: Office of Water, United States Environmental Protection Agency EPA-600-R-96-082, 1995).

[10] P. A. Roger, and S. A. Kulasooriya, Blue-Green Algae and Rice (Laguna, Philippines: International Rice Research Institute, 1980).

[11] P. A. Roger, and P. A. Reynaud, Ecology of blue-green algae in paddy fields, in W. G. Rockwood, and C. Mendoza (Eds.), Nitrogen and Rice (Los Banos, Philippines: International Rice Research Institute, 1979).

[12] C. Sobrino, and P. J. Neale, Short-term and long-term effects of temperature on photosynthesis in the diatom Thalassiosira pseudonana under UVR exposure, Journal of Phycology, 43, 2007, 426-436.

[13] J. F. Talling, Potassium - a non-limiting nutrient in fresh waters?, Freshwater Review, 3, 2010, 97-104.

[14] R. E. Lee, Phycology (New York: Cambridge University Press, 2008).

[15] D. R. Cullimmore, and A. E. McCann, Influence of four herbicides on the algal flora of a prairie soil, Plant Soil, 46, 1977, 499-510.

[16] A. Watanabe, The blue-green algae as the nitrogen fixators, 66th Symposium of International Congress for Microbiology, Moscou, C, 1967, 77-86.

[17] G. C. Odo, Studies on the ecology of macroinvertebrate fauna as fish food in Anambra River basin, Nigeria, doctoral thesis, University of Nigeria, Nsukka, 2004.

[18] G. O. Chukwu, Land suitability classification of southeastern Nigerian wetlands for Azolla, Scientific Research and Essays, 2 (12), $2007,512-515$.

[19] L. C. Uzozie, Distribution of food crops III: maize, rice and melon, in G. E. K. Ofomata (Ed.), Nigeria in maps: eastern states (Benin City, Nigeria: Ethiope Publishing House, 1975), 111-113.

[20] G. E. K. Ofomata, Relief, in G. E. K. Ofomata (Ed.), Nigeria in maps: eastern states (Benin City, Nigeria: Ethiope Publishing House, 1975), 2-3.

[21] P. C. Monanu, Rainfall in eastern Nigeria, in G. E. K. Ofomata (Ed.), Nigeria in maps: eastern states (Benin City, Nigeria: Ethiope Publishing House, 1975), 25-26.

[22] P.E.B. Inyang, Climatic regions, in G. E. K. Ofomata (Ed.), Nigeria in maps: eastern states (Benin City, Nigeria: Ethiope Publishing House, 1975), 27-29.

[23] J. C. Menakaya, Mineral and mining, in G. E. K. Ofomata (Ed.), Nigeria in maps: eastern states (Benin City, Nigeria: Ethiope Publishing House, 1975), 119-121.

[24] E. G. Bellinger, A Key to common algae: freshwater, estuarine and some coastal species (London: Institute of Water and Environment, 1992).

[25] G. W. Prescott, How to know the freshwater algae (Iowa: Dubuque, 1975).

[26] R. G. Wetzel, Limnology of lake and river ecosystems (New York: Elsevier Press, 2001).

[27] American Public Health Association, Standard methods for the examinations of water and waste water, $18^{\text {th }}$ edition, A. E. Greenberg, L. S. Clesceri, and A. D. Eaton (Eds.) (Washington DC: American Public Health Association, American Water Works Association, and Water Environmental Federation, 1992).

[28] United States Environmental Protection Agency, Methods for evaluating wetland condition: using algae to assess environmental conditions in wetland (Washington DC: Office of Water, U.S. Environmental Protection Agency, EPA-822-R-02-021, 2002).

[29] N. O. Nweze, and N. A. Domrufus, Limnological studies on Nike Lake Enugu, Enugu State - the metaphyton and some physicochemical aspect, Nigerian Journal of Botany, 19(2), 2006, 396-404.

[30] M. K. Mustapha, Seasonal influence of limnological variables on plankton dynamics of a small, shallow, tropical African reservoir, Asian Journal of Experimental Biological Sciences, 1 (1), 2010, 60 - 79.

[31] X. Zhou, and S. Kot, Heavy metals ion adsorbption on sediments of the Weiho and Hanjiang River, China, Journal of Environmental Hydrology, 3 (2), 1995,1-6.

[32] K. O. Adebowale, F. O. Agunbiade, and B. I. Olu - Owolabi, Impacts of natural and anthropogenic multiple sources of pollution on the environmental conditions of Ondo State coastal water, Nigeria, Electronic Journal of Environmental, Agricultural and Food Chemistry, 7 (4), 2008, $2797-2811$.

[33] M. A. F. Toufeek, and M. A. Korium, Factors controlling the distribution of the major metals in Lake Nasser water, AmericanEurasian Journal of Agricultural and Environmental Sciences, 5(6), 2009, 804-812.

[34] H. Ledo, N. Angulo, E. Gutierrez, and J. Mesa, Baseline metals concentrations in waters from a tropical binational river: the Catatumbo River, Venezuela, Journal of Environmental Hydrology, 14(26), 2006, 1-13. 